\title{
COLLABORATIVE WORK AMONG TEACHERS: A STUDY DEVELOPED AT THE POLYTECHNIC INSTITUTE OF BENGUELA
}

\author{
Joana Eduardo, Marta Abelha ${ }^{1,2,3}$, Filipa Seabra ${ }^{3}$, Ana Sofia Mota ${ }^{4}$ \\ ${ }^{1}$ Universidade Portucalense (PORTUGAL) \\ ${ }^{2}$ CEIS20 - University of Coimbra (PORTUGAL) \\ ${ }^{3} L E @ D$, Open University (UAb)(PORTUGAL) \\ ${ }^{4}$ IJP, Universidade Portucalense (PORTUGAL)
}

\begin{abstract}
As schools currently face increasing complexity, teachers' work requires the development and consolidation of collaborative work practices that contribute to more efficient and effective regulation of teaching and learning processes. Research carried out in the context of teachers' collaborative work has highlighted its importance as one of the factors of change, development and improvement of teaching organizations [1], [2], [3], [4]. Thus, teacher collaboration is urgent, and now is the time for teacher collaboration to be considered as an institutional objective.
\end{abstract}

In this sense, the primary purpose of this paper is to raise awareness about the dynamics of collaborative work among teachers from the Polytechnic Institute of Benguela. In order to respond to the research problem, three objectives were outlined, namely: i) to identify teachers' conceptions about teachers' collaborative work; ii) to characterize the work dynamics that teachers claim to develop and iii) to investigate factors that may facilitate or hinder the development of teachers' collaborative work.

The methodology adopted in this research assumed a primarily exploratory nature. The empirical study took place in the academic year of 2018 at the Polytechnic Institute of Benguela. The main data collection technique was a survey by questionnaire, applied to all of the institution's 94 teachers, with 76 validated answers. Descriptive statistical analysis was the data analysis technique used.

The main results of the study point to the predominance of teachers' individual work at the Polytechnic Institute of Benguela. They also reveal that teachers are aware of the benefits that collaborative work can bring to their professional development and express a willingness to experience more opportunities to develop collaborative work with colleagues.

Keywords: collaborative work, individualism, professional development.

\section{INTRODUCTION}

Society is continuously changing, a change that has been having an impact on the culture of school organizations. Currently, the school is, "increasingly confronted with such a complexity of issues that teachers' work (especially that which takes place in the classroom) demands the development and consolidation of collaboration practices (...) that contribute to a more efficient regulation of the teaching and learning processes" [1]. In this sense, the emergence of the "new" Education system law in Angola [5], aims, in our perspective, to encourage collaborative work dynamics, requiring teachers to develop joint efforts, mutual help and constant feedback, to overcome the problems diagnosed by the diversity of teaching and learning situations, inside and outside the classroom, thus contributing to the improvement of the educational system's quality in Angola.

Teachers collaboration is developed between a group of teachers, that is, as a team, in a relationship based on parity, where there is mutual help, working towards common goals, benefiting everyone. In this perspective Day [6] argues that teachers collaboration only occurs when teachers "talk about practice, observe each other in practice, work together in planning, evaluation and research on teaching and learning, and teach each other what they know about teaching, learning, and leadership". In this regard, several authors, theorizing about teachers collaboration, understand that the development of collaborative relationships between teaching professionals implies that teachers are open and available to share, listen, reflect, learn from their peers, creating more productive and satisfactory professional environments, without losing their identity, their professional independence and their capacity for critical analysis. In a teaching culture where collaboration prevails, teachers learn from each other: diversity, self-confidence, effectiveness and self-esteem are fostered, 
constituting a continuous training process and increasing the personal and professional development of the teacher. Thus, collaboration appears as a fundamental condition for the teacher's personal and professional growth, implying a change in educational practices and as such, in the quality of teaching, promoting a quality school.

There are several advantages pointed out by Hargreaves [4] considering collaboration, namely: i) moral support, since it reinforces the determination to act, and helps teachers to endure the failures and frustrations that often come with the initial moments of an educational change process; ii) increased efficiency, as it allows to overcome the repetition and redundancy of teachers and school subjects since activities are coordinated, and responsibilities are shared in a complementary way; iii) improved efficiency, as it encourages the diversity of teaching strategies, feedback among peers, and risks taking, resulting in the improvement of the quality of teaching and, consequently, in the improvement of the quality of student learning; iv) reduced workload, as it promotes the sharing of tasks and responsibilities by teachers; v) situated certainty, as it reduces feelings of uncertainty and enhances the development of collective professional confidence; vi) political affirmation, since it reinforces the security felt when adopting innovations that are introduced externally, as well as the moral strength to resist them when justified; vii) increased capacity of reflection, as it promotes dialogue and exchange of feedback among peers, making teachers reflect on their curricular practices to improve them; viii) learning opportunities, that is, collaboration increases the opportunities for teachers to learn from each other in the classroom, department and school, constituting a powerful source of professional learning and ix) continuous improvement, i.e., collaboration encourages teachers to consider change as a process of continuous improvement that will allow them to overcome diagnosed problems.

Despite the several potentialities recognized in the development of teaching collaboration practices, several authors (for example, [1], [4], [7], [8], [9]) warn that there may be various types of collaboration that serve different purposes and that they cannot always be considered as advantageous or even virtuous. We highlight the type of collaboration that Hargreaves [4] calls comfortable collaboration, as one of the possible forms of collaboration that does not extend to the context of the classroom, where teachers could teach under a co-teaching regime and/or carry out mutual observation and reflection on their teaching practices, to improve them. This type of collaboration is limited to sharing materials and ideas, not getting inside the classroom.

According to studies developed by Hargreaves [4], Neto-Mendes [10], Tardif \& Lessard [11] and Williams, Prestage \& Bedward [12] 'teachers' individualism is still the strategy privileged by teachers in general" [7]. It is a type of culture characterized fundamentally by contact with students in the classroom and by little contact with their peers [8]. Although collaborative work allows teaching more and better [13], this does not mean that we always work collaboratively, since collaboration implies that each individual has a contribution to make, and their process of individual and singular construction, which requires time and unique ways of working. The tasks of collaborative work among teachers can/should include moments of individual work to prepare or deepen the collective work in the next moment [14].

Therefore, we consider relevant that research on teachers' collaboration continues to be developed, for a better comprehension of the understanding among teachers about the concept of collaboration, of the factors that underlie the prevalence of teaching individualism and the conditions that may promote a teaching collaboration development.

\section{METHODOLOGY}

This section aims to explain the methodological options adopted in the empirical study developed, bringing into evidence "how the problematic was [empirically] researched and why certain methods and techniques were used" [15].

The methodology adopted in this work assumed an essentially exploratory and descriptive nature about the teachers' perceptions of the dynamics of collaborative teachers' work at the Polytechnic Institute of Benguela. In this way, the research problem is centered on the analysis and understanding of the dynamics of teachers' work established at the Polytechnic Institute of Benguela, and it translates into the following starting question:

How are the dynamics of collaborative teachers' work at the Polytechnic Institute of Benguela developed? 
In order to produce knowledge about this research problem, the following objectives were defined, namely:

1 To identify teachers' conceptions about collaborative teachers' work;

2 To characterize the work dynamics that teachers claim to develop;

3 To identify factors that may facilitate or hinder the development of collaborative teachers' work.

The primary data collection technique was a survey by questionnaire, applied to all of the institution's 94 teachers, with 76 validated answers.

The administered questionnaire was organized into two parts, namely:

Part I - Personal and Professional Characterization of the Respondent, whose set of questions allowed us to characterize the inquired teachers in terms of personal and professional aspects necessary for the study.

Part II - Dynamics of teachers' work, with a set of questions that made it possible to ascertain: i) the respondent's opinion on the definition of teaching collaboration; ii) how the respondent considers that teachers' work is developed at school, as well as at the level of the various curricular structures, pointing out the frequency with which he/she performs it (never, rarely, sometimes and often) in the various collaboration situations; iii) the respondent's opinion on the possible advantages of teachers' collaborative work and IV) the respondent's opinion on the potential difficulties encountered in the development of teachers' collaborative work practices.

Descriptive statistics analysis was the data treatment technique used.

\section{RESULTS}

The presentation and discussion of the results underly the research objectives and part of the theoretical framework underlying the present study.

\subsection{Characterization of Instituto Politécnico de Benguela (IPB)}

The IPB is located about seven kilometers from the city of Benguela, in the neighborhood of Nossa Senhora da Graça, in the commune of zone $F$ (the main reference is the chapel of Nossa Senhora da Graça), in the north of the municipality of Benguela, in the province with the same name (one of the eighteen provinces of Angola) located specifically in western Angola. Its territorial area is $2,100 \mathrm{~km} 2$ with about 513,441 inhabitants according to the second population census of 2014 .

The IPB, promoting Technical-Professional Education, is a public school of secondary education (from the 10th to the 13th grade; on daytime and post-work regime) designed to train staff on technical, technological and practical skills in various areas of professional training (in Mechanics, with the Cold and Air Conditioning Course, in Environment, with the Environmental Management course and in Electricity, with the Industrial Electronics and Automation, Energy and Electrical Installations and Renewable Energy courses), aiming the future access of students to the job market.

Regarding the academic year of 2018 (when the empirical study took place), IPB enrolled 1,491 students in the various courses, as follows:

Table 1. List of students by training area / course.

\begin{tabular}{l|c|c|c}
\hline \multicolumn{1}{c|}{ Training area / course } & Male No. & Female No. & Total No. \\
\hline Cold and Air Conditioning & 358 & 71 & 429 \\
\hline Environmental Management & 67 & 140 & 207 \\
\hline Energy and Electrical Installations & 380 & 79 & 459 \\
\hline Industrial Electronics and Automation & 184 & 31 & 215 \\
\hline Renewable energy & 145 & 36 & 181 \\
\hline Total & 1134 & 357 & 1491 \\
\hline \hline
\end{tabular}


The courses that received more students were Energy and Electrical Installations ( $n=490$ students) and Cold and Air Conditioning ( $n=429$ students), with a strong predominance of males.

Concerning the ratio of students by school year, number of classes and gender, we present the following table:

Table 2. List of students by school year, number of classes and gender.

\begin{tabular}{l|c|c|c|c}
\hline \hline School year & No. of classes & Male No. & Female No. & Total No. \\
\hline 10th Grade & 16 & 439 & 135 & 574 \\
\hline 11th Grade & 14 & 346 & 116 & 462 \\
\hline 12th Grade & 13 & 257 & 76 & 333 \\
\hline 13th Grade & 4 & 92 & 30 & 122 \\
\hline Main Total & 47 & 1134 & 357 & 1491 \\
\hline \hline
\end{tabular}

We can see that as we progress in the school year, the number of classes decreases, quite significantly in the 13th grade.

Table 3 shows the number of teachers that in the academic year of 2018 were teaching at IPB, and their respective academic qualifications. With a total of 94 teachers, 69 are male, and 25 are female.

Table 3. List of teachers by gender and academic degree.

\begin{tabular}{l|c|c|c}
\hline \multicolumn{1}{c|}{ Academic degree } & Male No. & Female No. & Total No. \\
\hline High school degree & 2 & 1 & 3 \\
\hline Bachelor Degree & 9 & 5 & 14 \\
\hline Graduation Degree & 40 & 10 & 50 \\
\hline Post-Graduation & 8 & 2 & 10 \\
\hline Master & 10 & 7 & 17 \\
\hline Ph.D. & --- & --- & -- \\
\hline Total & 69 & 25 & 94 \\
\hline \hline
\end{tabular}

It should be noted that about half of the teachers have a Bachelor's Degree and the majority are male.

\subsection{Personal and professional characterization of participating teachers}

Table 4 shows us that the male gender is predominant $(76 \%)$ compared to the female $(24 \%)$ regarding the teachers participating in the study. Eventually, the nature of the courses taught at IPB is associated to this predominance.

Table 4. Teachers' gender.

\begin{tabular}{l|c|c|c}
\hline \multicolumn{1}{c|}{ Gender } & Frequency & $\%$ & Total \\
\hline Male & 58 & $76 \%$ & \multirow{2}{*}{76} \\
\hline Female & 18 & $24 \%$ & \\
\hline \hline
\end{tabular}

According to the data presented in table $5,43 \%$ of the respondent teachers are between 26 to 35 years old; $42 \%$ of respondent teachers are between 36 and 50 years old. We can thus verify that the teaching staff from IPB is relatively young. 
Table 5. Teachers' age.

\begin{tabular}{l|c|c|c}
\hline \multicolumn{1}{c|}{ Age } & Frequency & $\%$ & \multirow{2}{*}{ Total } \\
\cline { 1 - 3 } To 25 & 0 & $0 \%$ & \\
\cline { 1 - 3 } From 26 to 35 & 33 & $43 \%$ & \multirow{2}{*}{76} \\
\cline { 1 - 3 } From 36 to 50 & 32 & $42 \%$ & \\
\cline { 1 - 3 }$>$ > than 50 & 11 & $15 \%$ & \\
\hline \hline
\end{tabular}

As we can see in table $6,61 \%$ of the respondent teachers have a Graduation degree, followed by a Master's degree, with 21\%, 9\% have some Postgraduate degree, and $8 \%$ have a Bachelor's degree.

Table 6. Academic Qualifications of respondents.

\begin{tabular}{l|c|c|c}
\hline \hline \multicolumn{1}{c|}{ Academic qualifications } & Frequency & $\%$ & Total \\
\hline Ph.D. & 0 & $0 \%$ & \\
\hline Master & 16 & $21 \%$ & \\
\cline { 1 - 2 } Post-graduation & 7 & $9 \%$ & \multirow{2}{*}{76} \\
\cline { 1 - 2 } Graduation & 46 & $61 \%$ & \\
Bachelor & 6 & $8 \%$ & \\
\hline Other: 2nd Year Engineering & 1 & $1 \%$ & \\
\hline \hline
\end{tabular}

The data in table 7 refers to the teachers' employment situation, with $92 \%$ of the respondent teachers being effective, which contributes to the stability of the teaching staff and, consequently, constitutes an asset for the teaching and learning processes.

Table 7. The employment situation of respondents.

\begin{tabular}{l|c|c|c}
\hline \hline \multicolumn{1}{c|}{ Employment situation } & Frequency & $\%$ & \multirow{2}{*}{ Total } \\
\hline Probationary & 5 & $7 \%$ & \\
\cline { 1 - 2 } Fixed-term & 70 & $92 \%$ & \multirow{2}{*}{76} \\
\cline { 1 - 2 } Other. Which one? Collaborator & 1 & $1 \%$ & \\
\hline \hline
\end{tabular}

\subsection{Answers to research objectives (RO)}

\subsubsection{RO 1:Identify teachers' conceptions about the concept of collaborative work}

Given the results presented in table 8 , we conclude that the IPB teachers are in line with the theoretical perspectives [4], [14] that argue that teachers' collaborative work cannot be limited to the sharing of pedagogical materials (also important and recognized by $14 \%$ of participating teachers) comfortable collaboration -, however it has to go further (inside the classroom). However, the option that refers to teaching collaboration as a "joint decision making process, careful negotiation, where effective communication and trust levels are established", was only chosen by $6 \%$ of the respondent teachers, which denotes some weakness in the conception of work collaborative teaching, since it must be structured "essentially as an articulated and jointly decided upon work process, that leads to reaching better results" [14]. 
Table 8. Understanding the concept of teachers' collaborative work.

\begin{tabular}{|c|c|c|}
\hline In your opinion, what does teachers' collaborative work consist of? Choose three options. & Frequency & $\%$ \\
\hline Planning and preparing activities of "extra-school" nature & 24 & $11 \%$ \\
\hline Sharing and elaborating together teaching materials to be used in the classroom & 32 & $14 \%$ \\
\hline Situations in which teachers work collaboratively, at the level of meetings & 25 & $11 \%$ \\
\hline Collaborative and articulated effort to understand and analyze problematic situations & 21 & $9 \%$ \\
\hline $\begin{array}{l}\text { Talking about practice, observing each other in practice, working together planning and } \\
\text { evaluating teaching and learning, and teaching each other about teaching and learning }\end{array}$ & 27 & $12 \%$ \\
\hline Placing a group of teachers before a collective task & 20 & $9 \%$ \\
\hline Mutual help in which everyone works to achieve common goals and benefits & 22 & $10 \%$ \\
\hline $\begin{array}{l}\text { Joint decision-making, careful negotiation where levels of significant trust and communication } \\
\text { are established }\end{array}$ & 14 & $6 \%$ \\
\hline $\begin{array}{l}\text { Enhancing interaction, dialogue and reflection together, thus increasing possibilities of mutual } \\
\text { learning }\end{array}$ & 17 & $7 \%$ \\
\hline $\begin{array}{l}\text { Sharing responsibilities concerning work orientations and being able to find solutions together } \\
\text { to diagnosed problems }\end{array}$ & 26 & $11 \%$ \\
\hline
\end{tabular}

\subsubsection{RO 2: Characterize work dynamics that teachers claim to develop}

Analyzing the data presented in table 9 , we can see that "individual work" is mentioned with a frequency of "often" by $45 \%$ of the respondent teachers, in line with the results obtained in other investigations ([7] [16], [10], [17]) that demonstrate that teachers' work is mostly individual and lonely. A balkanized teachers' work culture seems to prevail at the IPB, where teachers come together in smaller work subgroups, whose training criterion is to belong to the same curricular subject group and grade that they teach (67\%), a result in line with the theoretical perspective by Hargreaves [4].

It should be noted that the balkanization of professional teaching life according to disciplinary criteria, contributes to a segmented and hierarchical view of the school, according to academic knowledge [7].

Table 9. How teachers claim to develop their work at school.

\begin{tabular}{|c|c|c|c|c|c|c|c|c|}
\hline \multirow[b]{2}{*}{$\begin{array}{c}\text { Considering the way you perform teachers' work, choose } \\
\text { the frequency with which you develop situations: }\end{array}$} & \multicolumn{2}{|c|}{ Never } & \multicolumn{2}{|c|}{ Rarely } & \multicolumn{2}{|c|}{ Sometimes } & \multicolumn{2}{|c|}{ Often } \\
\hline & 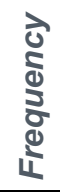 & dீ & 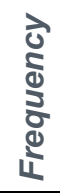 & do & 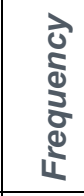 & ১ீ & 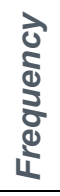 & ১ீ \\
\hline Individual work & 10 & $13 \%$ & 15 & $20 \%$ & 17 & $22 \%$ & 34 & $45 \%$ \\
\hline $\begin{array}{l}\text { Work with colleagues with whom you feel greater } \\
\text { emotional closeness }\end{array}$ & 7 & $9 \%$ & 8 & $11 \%$ & 35 & $46 \%$ & 26 & $34 \%$ \\
\hline $\begin{array}{l}\text { Work with colleagues who teach the same subject, but not } \\
\text { the same school grade }\end{array}$ & 6 & $8 \%$ & 5 & $7 \%$ & 20 & $26 \%$ & 45 & $59 \%$ \\
\hline $\begin{array}{l}\text { Work with colleagues from your curricular area, who teach } \\
\text { the same subject and the same school year }\end{array}$ & 3 & $4 \%$ & 3 & $4 \%$ & 19 & $25 \%$ & 51 & $67 \%$ \\
\hline Work with colleagues from another curricular area & 7 & $9 \%$ & 37 & $49 \%$ & 30 & $39 \%$ & 2 & $3 \%$ \\
\hline
\end{tabular}

Regarding the development of collaborative work in the different curricular structures, the Class Council is the structure that teachers point out $(36 \%)$ as the structure in which more collaborative work between teachers is developed, followed by the Pedagogical Council $(29 \%)$ and Curricular subject group (22\%). 
Table 10. Frequency of collaborative work at the level of the various curricular structures.

\begin{tabular}{|c|c|c|c|c|c|c|c|c|}
\hline \multirow[b]{2}{*}{$\begin{array}{l}\text { Considering how teachers' work is developed at the } \\
\text { various curricular structures level, choose the } \\
\text { frequency with which you develop collaborative work, } \\
\text { at the level of: }\end{array}$} & \multicolumn{2}{|c|}{ Never } & \multicolumn{2}{|c|}{ Rarely } & \multicolumn{2}{|c|}{ Sometimes } & \multicolumn{2}{|c|}{ Frequently } \\
\hline & 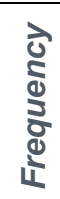 & dீ & 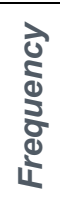 & dீ & 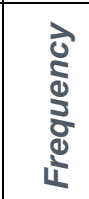 & dீ & 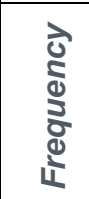 & ১ீ \\
\hline School Management & 26 & $34 \%$ & 22 & $29 \%$ & 17 & $22 \%$ & 11 & $14 \%$ \\
\hline Pedagogical Council & 20 & $26 \%$ & 8 & $11 \%$ & 26 & $34 \%$ & 22 & $29 \%$ \\
\hline Curricular subject group & 20 & $26 \%$ & 21 & $28 \%$ & 18 & $24 \%$ & 17 & $22 \%$ \\
\hline Class Council & 7 & $9 \%$ & 9 & $12 \%$ & 33 & $43 \%$ & 27 & $36 \%$ \\
\hline Other. Extra-curricular activities & 73 & $96 \%$ & 0 & $0 \%$ & 3 & $4 \%$ & 0 & $0 \%$ \\
\hline
\end{tabular}

\subsubsection{RO 3: Identify factors that enhance and inhibit collaborative teachers' work}

The main advantages identified by the teachers (see Table 11) about collaborative teachers' work are that it constitutes a valuable resource since the elements that form a group join forces towards action and determination, and that through dialogue, interaction and joint reflection obstacles are overcome, enabling change and innovation [8] and having an impact on teaching and learning processes.

Table 11. Advantages of collaborative teachers' work.

\begin{tabular}{l|c|c}
\hline \hline Choose four advantages that result from the development of collaborative teachers' work. & Frequency & $\%$ \\
\hline Reduces teacher isolation & 13 & $4 \%$ \\
\hline Allows elaboration and sharing of material resources, ideas and experiences & 45 & $15 \%$ \\
\hline $\begin{array}{l}\text { Allows planning and development of a set of activities to be carried out with students in the } \\
\text { classroom }\end{array}$ & 50 & $16 \%$ \\
\hline Allows a collaborative reflection on teaching practices & 28 & $9 \%$ \\
\hline Promotes interdisciplinarity, enhancing collaborative development of interdisciplinary projects & 20 & $7 \%$ \\
\hline $\begin{array}{l}\text { Promotes collaborative curriculum management through the adoption of differentiated and } \\
\text { appropriate teaching strategies for different students, enhancing students' learning }\end{array}$ & 27 & $9 \%$ \\
\hline $\begin{array}{l}\text { Allows collaborative elaboration of suitable information related to students' learning and } \\
\text { assessment processes, to provide to parents and other caregivers }\end{array}$ & 30 & $10 \%$ \\
\hline Enables a better teaching performance & 40 & $13 \%$ \\
\hline Enhances interpersonal relationships between teachers & 22 & $7 \%$ \\
\hline Promotes collaborative analysis and discussion of students' assessment criteria & 27 & $9 \%$ \\
\hline Does not recognize added value in the development of teachers' collaborative work & 2 & $1 \%$ \\
\hline \hline
\end{tabular}

Regarding the factors that seem to hinder higher levels of teachers' collaborative work (see Table 12), teachers pointed out: the prevalence of a culture of teaching individualism with a frequency of $13 \%$; the teacher's unavailability for collaborative work, with a frequency of $13 \%$; teachers' work centered on the fulfilment of program content with a percentage of $11 \%$; and the absence of good professional relationships, in a percentage of $10 \%$.

The results about teachers' work centralized in the fulfilment of the syllabus are in line with Roldão's theory [14] when the author argues that this situation constitutes a constraint to the development of collaboration since the predominance of curricular normativity leads more to a sense of compliance than to a sense of effectiveness and quality.

Teacher's unavailability for collaborative work was another factor pointed out as a constraint to the development of collaborative work. According to Hargreaves [4], this unavailability may be due to one of these types of individualism, namely: i) elective individualism - in which the teacher motivated by insecurity or fear of criticism from peers refers to isolation; ii) constrained individualism - which is motivated by the physical and administrative conditions that guide teaching work, and iii) strategic 
individualism - which results from a strategic option of the teacher who considers that time and energy should be dedicated to the teaching process in the classroom.

Table 12. Inhibiting factors of collaborative teachers' work.

\begin{tabular}{l|c|c}
\hline \hline Choose four difficulties that you consider to limit collaborative teachers' work the most. & Frequency & $\%$ \\
\hline The pervasiveness of a culture of individualism & 41 & $13 \%$ \\
\hline Lack of professional stability & 29 & $10 \%$ \\
\hline Teachers' work effort centralized in the compliance of curricular program content & 34 & $11 \%$ \\
\hline Lack of good personal relationships & 31 & $10 \%$ \\
\hline Lack of good professional relationships & 34 & $11 \%$ \\
\hline Exceeding activities at school that hinder collaborative work & 14 & $5 \%$ \\
\hline Lack of physical spaces suitable to gather and to work collaboratively & 17 & $6 \%$ \\
\hline Lack of compatibility regarding teachers extra-teaching timetables & 27 & $9 \%$ \\
\hline Nonexistent leadership capable of promoting collaborative work & 18 & $6 \%$ \\
\hline Teachers' apprehensiveness about working collaboratively & 21 & $7 \%$ \\
\hline Teachers' unavailability for working collaboratively & 38 & $13 \%$ \\
\hline \hline
\end{tabular}

In short, according to the results obtained, at the Polytechnic Institute of Benguela, teachers'individual work prevails over collaborative work. This situation, combined with the unavailability of teachers for collaborative work (13\%) and the lack of good professional relationships $(11 \%)$, can hinder feedback between teachers and effective curriculum development, as well as professional development, allowing a type of work centralized in the fulfilment of programmatic contents.

\section{CONCLUSIONS}

A fundamental objective of this study was to raise awareness about the dynamics of collaborative work among teachers of the Polytechnic Institute of Benguela, as we believe that teacher collaboration is one of the factors of change, development and improvement of school organizations [1], [2], [3], [4]. In this sense, we can conclude that even though the teachers from IPB value collaborative work (considered better, more supportive and less competitive), data indicates a prevalence of individual work (the work done behind closed doors).

Being aware that this research subject does not end with the present research, we dare to launch a set of proposals that could induce higher levels of development of collaboration among teachers, particularly in the institution where the study was conducted, namely:

1 Promotion of training actions within the scope of teaching collaboration that would involve teachers from different curricular areas;

2 Presentation of this investigation results at IPB and their discussion, in a reflexive way, with the teachers and the management team;

3 Awareness of the management team towards the need to create organizational conditions that would promote collaborative teacher development;

4 Reassessment of the initial teacher practice that should train future teachers based on a logic of collaboration.

\section{REFERENCES}

[1] M. Abelha and E. Machado, "Supervisão, colaboração e formação: relato de uma experiência com docentes de um agrupamento TEIP," Revista de Estudos Curriculares, vol. 9, no. 1, pp. 103121, 2018. Retrieved from http://hdl. handle. net/11328/2493.

[2] I. Alarcão and B. Canha, Supervisão e colaboração: uma relação para o desenvolvimento. Porto: Porto Editora, 2013. 
[3] I. Alarcão and M. Roldão, Supervisão: um contexto de desenvolvimento profissional dos professores. Mangualde: Edições Pedago, 2008.

[4] A. Hargreaves, Os professores em tempos de mudança. Alfragide: McGraw-Hill, 1998.

[5] Lei $n^{\circ}$ 17/16. Lei de Base do Sistema da Educação em Angola, D.R. I Série, vol. 170 (7-10-2016), pp. 3994-4013, 2016.

[6] C. Day, A paixão pelo ensino. Porto: Porto Editora, 2004.

[7] M. Abelha, Trabalho colaborativo docente na gestão do currículo do Ensino Básico: do discurso às práticas, Ph.D. Thesis. Aveiro: Universidade de Aveiro, 2011.

[8] F. Leite, Trabalho colaborativo entre docentes num território educativo de intervenção prioritária: estudo de caso, Ph.D. Thesis. Porto: Universidade Portucalense, 2015.

[9] A. Neto-Mendes, "O professor do ensino secundário: da organização escolar às culturas docentes" in Conhecimento profissional de professores: a praxis educacional como paradigma de construção (J. Tavares and I. Brzezinski, orgs.), pp. 113-132, Fortaleza: Edições Demócrito Rocha, 2001.

[10] A. Neto-Mendes, $O$ trabalho dos professores e a organização da escola secundária. individualismo e colegialidade numa perspectiva sócio-organizacional. Ph.D. Thesis. Universidade de Aveiro, Portugal, 1999.

[11] M. Tardif and C. Lessard, O trabalho docente: elementos para uma teoria da docência como profissão de interacções humanas. Petrópolis: Editora Vozes, 2005.

[12] A. Williams, S. Prestage and J. Bedward, "Individualism to Collaboration: the significance of teacher culture to the induction of newly qualified teachers," Journal of Education for Teaching, vol. 27, pp. 253-267, 2001.

[13] M. A. Tavares, Professor, currículo e mudança. a reforma educativa em Angola. Benguela: Editor Paulo Cardo, 2015.

[14] M. Roldão, "Colaborar é preciso: questões de qualidade e eficácia no trabalho dos professores," Revista Noesis, vol. 71, pp. 24-29, 2007.

[15] J. Bell, Como realizar um projecto de investigação. Lisboa: Gradiva, 2004.

[16] M. Abelha, E. A. Machado and C. Lobo," Colaboração docente em contexto educativo angolano: potencialidades e constrangimentos," in Trabalho Docente e Formação: Políticas, Práticas e Investigação: pontes para a mudança, (A. Lopes, M. Cavalcante, D. Oliveira and A. Hipólito (Orgs.). Atas do II Encontro Luso-Brasileiro sobre o Trabalho Docente e Formação, pp.53685380. Porto: CIIE - Centro de Investigação e Intervenção Educativas, 4014.

[17] M. G. Thurler, "Levar os professores a uma construção activa da mudança. Para uma nova concepção da gestão da inovação" in A escola e a mudança (M. G. Thurler and P. Perrenoud, eds.), pp. 33-59, Lisboa: Escolar Editora, 1994. 